\title{
Selective Intervention and Internal Hybrids: Interpreting and Learning from the Rise and Decline of the Oticon Spaghetti Organization
}

\author{
Nicolai J. Foss \\ LINK, Department of Industrial Economics and Strategy, Copenhagen Business School, \\ Solbjergvej 3; 2000 Frederiksberg, Denmark \\ njf.ivs@cbs.dk
}

\begin{abstract}
Infusing hierarchies with elements of market control has become a much-used way of simultaneously increasing entrepreneurialism and motivation in firms. However, this paper argues that such "internal hybrids," particularly in their radical forms, are inherently hard to successfully design and implement because of a fundamental incentive problem of establishing credible managerial commitments to not intervene in delegated decision making. This theme is developed and illustrated, using the case of the world-leading hearing aids producer, Oticon. In the beginning of the 1990s, Oticon became famous for its radical internal hybrid, the "spaghetti organization." Recent work has interpreted the spaghetti organization as a radical attempt to foster dynamic capabilities by organizational means, neglecting, however, that about a decade later the spaghetti organization has given way to a more traditional matrix organization. In contrast, an organizational economics interpretation of Oticon organizational changes is developed. This lens suggests that a strong liability of the spaghetti organization was the above incentive problem: Frequent managerial meddling with delegated rights led to a severe loss of motivation, and arguably caused the change to a more structured organization. Refutable implications are developed, and the discussion is broadened to more general issues of economic organization.

(Internal Hybrids; Organizational Change; Delegation; Managerial Commitment Problems; New Organizational Forms)
\end{abstract}

\section{Introduction}

In academic research as well as in managerial practice, the search for the sources of competitive advantage has increasingly centered on organization-related factors (e.g., Barney 1986, Kogut and Zander 1992, Mosakowski 1998, Nahapiet and Ghoshal 1999). Thus, it is argued that many firms radically change the way in which they structure their boundaries (e.g., Helper et al. 2000) as well as their internal organization (e.g., Miles et al. 1997). They arguably do this in an attempt to foster the dynamic capabilities that are necessary for competing in the emerging knowledge economy. Fundamental advances in IT and measurement technologies have facilitated these changes (Zenger and Hesterly 1997), while equally fundamental developments in the organization and motives of capital markets as well as increasing internationalization are claimed to have made them necessary (Halal and Taylor 1998).

From an organizational economics perspective, these experiments with economic organization fall into the categories of either external hybrids (Williamson 1996) (that is, market exchanges infused with elements of hierarchical control), or internal hybrids (Zenger 2002) (that is, hierarchical forms infused with elements of market control). The aims of the experimental efforts are to reduce coordination costs, improve incentives, and help to clarify the nature of the businesses the firm is in, thereby improving entrepreneurial capabilities and the ability to produce, share, and reproduce knowledge (Grant 1996, Day and Wendler 1998, Miles et al. 1997, Mosakowski 1998). Although both internal and external hybrids are means to reach these aims, they would seem to be highly imperfect substitutes. For example, adopting an internal hybrid form has the benefit of involving fewer layoffs relative to adopting external hybrids. Also, spin-offs, carve-outs and the like are often legally complex operations, whereas adopting an internal hybrid may simply be a matter of managerial fiat. Further, management may fear that leaving too many activities in the hands of other firms will hollow out the corporation (Teece et al. 1994), or make it difficult to protect valuable knowledge (Liebeskind 1996). Given this, one may wonder why firms should ever make governance choices in favor of external hybrids. However, a main point of this paper is that internal hybrids are beset by distinct incentive costs that external hybrids tend to avoid, and 
that this may explain why external hybrids are chosen over internal hybrids.

Research on new organizational forms is an emerging field (Daft and Lewin 1993, Zenger and Hesterly 1997, Foss 2002), and rather little is known about the costs and benefits of these organizational forms. ${ }^{1}$ This paper mixes empirical observation with theoretical reasoning, mostly drawn from organizational economics, in order to gain a better understanding of the organizational design problems of internal hybrids. The theoretical emphasis is on the (neglected) costs of internal hybrids, and in particular on motivational and commitment problems that derive from the delegation of decision rights. The root of such problems is that in firms, (delegated) decision rights are not owned; they are always loaned from the holder(s) of ultimate decision-making rights, namely the top management and/or the shareholders. Given this, a fundamental problem for top management/owners is to commit to real delegation and refrain from selective intervention (Williamson 1996) that harms motivation, and may reduce effort and investments in firm-specific human capital.

These ideas are developed and discussed empirically with reference to organizational changes that took place in the Danish electronics (primarily hearing aids) producer, Oticon A/S, beginning in 1991. Oticon became world famous for its radical delegation experiment. The "spaghetti organization," as it came to be called, was explicitly conceived of by its designers as an attempt to infuse the Oticon organization with strong elements of market control (Kolind 1990, Lyregaard 1993) and was seen as a hard-to-replicate source of knowledge-based competitive advantage (e.g., Gould 1994). In fact, a recent cottage industry has treated the Oticon experience as an outstanding example of the sustained benefits that radical project-based organizations may provide (e.g., Lovas and Ghoshal 2000, Ravasi and Verona 2000, Verona and Ravasi 1999). However, his literature fails to note that the spaghetti organization in its initial radical form does not exist anymore; it has been superseded by more structured administrative systems since around 1996. In the following, these organizational changes will be discussed from an organizational economics starting point. The approach followed with respect to understanding the nature of organizational changes in Oticon is a historical one that relies heavily on the large number of thick descriptions of Oticon that have been produced by a number of mainly Danish academics, journalists, and Oticon insiders throughout the 1990s (in particular, Lyregaard 1993; Poulsen 1993; Morsing 1995; Morsing and Eiberg 1998; Eskerod 1997,
1998; Jensen 1998). However, these sources were supplemented with semistructured interviews with the prime mover behind the spaghetti experiment, then-CEO, Lars Kolind, as well as the present Oticon HRM officer (both June 2000).

The paper begins by developing an organizational economics interpretation of the spaghetti organization (The Spaghetti Organization: A Radical Internal Hybrid). The spaghetti organization appears to have been a particularly well-crafted internal hybrid. Still, it gave way to a more traditional matrix structure. It is not plausible to ascribe this organizational change to outside contingencies or to dramatic changes in strategic intent. This suggests that the spaghetti organization may have been beset by organizational costs that came to dominate the benefit aspects, necessitating a change of administrative systems (Spaghetti and Beyond). The Oticon spaghetti experiment carries lessons for the design of internal hybrids. In particular, it directs attention to the incentive problems of delegating rights within a firm when top management keeps ultimate decision rights. Refutable propositions for the design of internal hybrids are derived (Discussion: Implications for Internal Hybrids).

It should be clear already at this stage that the following is an attempt to pursue a specific interpretation of the Oticon spaghetti episode. Organizational economics per se is hardly in an early stage of theory development anymore, given that early work goes back more than six decades (Coase 1937), and the last three decades have witnessed a flurry of work in this field. There is therefore little need for following a logic of grounded theory (Glaser and Strauss 1967). Moreover, organizational economics is a particularly appropriate tool of interpretation in the present context, because only this body of theory simultaneously frames internal hybrids theoretically, casts the analysis in the relevant comparativeinstitutional terms (e.g., allows comparison of external and internal hybrids), and frames the kind of incentive problems that will be central in the following analysis. For example, neither information processing or motivation theory can accomplish all this. ${ }^{2}$

In sum, the contributions of this paper are to (1) present a novel, and in key respects more encompassing, account and interpretation of a well-known organizational change case, exemplifying the interpretive usefulness of organizational economics in the process; (2) analyze the (neglected) costs of internal hybrids in terms of the problem of selective intervention, thus contributing to understanding the efficient design of such hybrids; and (3) argue that the analysis under (2) is also helpful for understanding broader issues of economic 
organization, such as the governance choice between internal and external hybrids.

\section{The Spaghetti Organization: A Radical Internal Hybrid}

Recent work has used the Oticon Spaghetti experiment for the purpose of developing notions of strategy making as "guided evolution" (Lovas and Ghoshal 2000), and to discuss how the deliberate introduction of "structural ambiguity" through the choice of loosely coupled administrative systems (Ravasi and Verona 2000) may help to build "organizational capabilities for continuous innovation" (Verona and Ravasi 1999). This literature places all of the emphasis on the benefit side (mostly innovation performance) of the spaghetti experiment and fails to note that (and explain why) the spaghetti organization has been largely abandoned. In contrast, this paper accounts for the costs of this particular internal hybrid in terms of organizational economics, and uses this account to explain the change from the spaghetti organization.

\section{Oticon: Background}

Founded in 1904 and based mainly in Denmark, Oticon (now William Demant Holding A/S) is a world leader in the hearing aids industry. ${ }^{3}$ In the first part of the 1990s, Oticon became a famous and admired instance of radical organizational change. CEO Lars Kolind and his new organizational design became favorites of the press, consultants, and academics alike. ${ }^{4}$ The new organization was cleverly marketed as the very embodiment of empowering project-and team-based organization. Moreover, it quickly demonstrated its innovative potential by re-vitalizing important, but "forgotten" development projects that, when implemented in the production of new hearing aids, produced significant financial results, essentially saving the firm from a threatening bankruptcy, as well as by turning out a number of new strong spin-off products. The background to the introduction of the spaghetti organization was the loss of competitive advantage that Oticon increasingly suffered during the 1980s as a result of increasingly strong competition (mainly from the United States). Also, a change in the technological paradigm (Dosi 1982) in the hearing aids industry was gradually taking place through the 1980s from "behind-the-ear" hearing aids to "inthe-ear" hearing aids (Lotz 1998). Oticon's success in the 1970s was founded on miniaturization capabilities. While these had been critical for competitive advantage in the "behind-the-ear" hearing aid paradigm, new technological capabilities in electronics which were not under in-house control by Oticon were becoming crucially important in the emerging in-the-ear paradigm.

There is evidence (e.g., Poulsen 1993, Gould 1994, Morsing 1995) that at the end of the 1980s Oticon was locked into a competence trap that was reinforced by strong groupthink characterizing both the management team and the employees. A symptom of this was that the dominant opinion among managers and development personnel at Oticon was that the in-the-ear hearing aid would turn out to be a commercial fiasco. Moreover, in-the-ear hearing aids were not perceived to be Oticon turf, in terms of both technological and marketing capabilities (Poulsen 1993). The self-image of the company clearly was one of being a traditional industrial company with its strongest technological capabilities in miniaturization and specializing in mass-producing behind-theear hearing aids, developing the underlying technology incrementally. Administrative systems were organized traditionally with functional departments, the managers of which together constituted the senior executive group. When problems began to accumulate, various attempts were made to change the situation, which, however, were either too insignificant or did not survive political jockeying inside Oticon. In 1988, Lars Kolind assumed the position of new CEO, concentrated all decision-making power in his own hands, and implemented drastic costcutting measures. However, he also quickly realized that something else had to be done to cope with the decisive changes that were underway with respect to products and processes in the industry. More radical measures were needed with respect to the strategic orientation of the firm, the administrative systems that could back this up, and the technology that the firm sourced, leveraged, and developed.

\section{Trying Spaghetti}

The new, radical measures were first sketched in a sixpage memo (Kolind 1990), which described a fundamental change of corporate vision and mission: The company should be defined broadly as a first-class service firm with products developed and fitted individually for customers, rather than narrowly, as a manufacturing company producing standard behind-the-ear hearing aids. A new organizational form, namely the "spaghetti organization" (called so in order to emphasize the point that it should be able to change rapidly, yet still possess coherence), would support this strategic reorientation. The new form should be explicitly "knowledge-based," that is, consisting of "... knowledge centres...connected by a multitude of links in a nonhierarchical structure" (Kolind 1994, pp. 28-29). Making the organization "anthropocentric," that is, designing 
jobs so that these would “... fit the individual person's capabilities and needs" (ibid., p. 31), was argued to provide the motivational support for this knowledge network. Furthermore, basing the network on "free market forces" (Lyregaard 1993) would make it capable of actually combining and recombining skills in a flexible manner, where skills and other resources would move to those (new) uses where they were most highly valued. Clearly, the aim was to construct a spontaneously working internal network that would work with only minimal intervention on the part of Kolind and other managers, that is, "essentially, a free market at work" (LaBarre 1996).

The new organizational form was primarily implemented in the Oticon headquarters (i.e., administration, research and development, and marketing). To symbolically underscore the fundamental transformation of Oticon, headquarters moved at 8 am on 8 August 1991 to a completely new location north of Copenhagen. In the new building, all desks were placed in huge, open office spaces, and employees did not have permanent desks, but would move depending on which projects they were working on. The number of formal titles was drastically reduced, resulting in a two-layered structure with Kolind and 10 managers representing the managerial team and the remaining part of the organization being organized into projects (Kolind 1994). Thus, the new organization represented a breakdown of the old functional department-based organization into an almost completely flat, project-based organization. Departments gave way to "Competence Centers" (e.g., in mechanical engineering, audiology, etc.) that broke with the boundaries imposed by the old departments. The "multijob" concept represented a notable break with the traditional division of labor in organizations. It was based on two key features: First, there were no restrictions on the number of projects that employees could voluntarily join, and, second, employees were actively encouraged (and in the beginning actually required) to develop and include skills outside of their existing skill portfolio. ${ }^{5}$ The underlying notion was that this would increase the likelihood that project teams would consist of the right mix of complementary skills and knowledge, because of the increase in the scope of the knowledge controlled by each team member. Moreover, the multijob concept would ease knowledge transfer because of the increase in the overlap of knowledge domains that it would produce, as employees familiarized themselves with other employees' specialized fields.

These changes were accompanied by an extensive delegation of the rights to make decisions on resource allocation. Notably, employees would basically decide themselves which projects they would join rather than being assigned to tasks and projects from "above." Project managers were free to manage projects in their preferred ways. Wage negotiations were decentralized, with project managers receiving the right to negotiate salaries. ${ }^{6}$ Finally, although project teams were selforganizing and basically left to mind their own business once their projects were ratified, they were still required to meet with a "Projects and Products Committee" once every three months for ongoing project evaluation.

To meet the two potentially conflicting aims of making it possible for project teams to rapidly and flexibly combine the right skills, and achieving overall coherence between rather independently taken decisions, the new organization was founded on four fundamental ideas (Kolind 1994). First, as noted, the traditional functional department structure was eliminated in favor of a project organization that went considerably beyond the traditional matrix structure. While this served to increase flexibility, other measures were directed towards achieving organizational coherence. Thus, secondly, new information technology systems were designed and implemented to make it possible to coordinate plans and actions in this decentralized organization. Everybody was supposed to have full access to the same information. Third, the traditional concept of the office was abandoned, as already mentioned. Finally, Kolind worked hard to increase intrinsic motivation by developing a corporate value base that strongly stressed responsibility, personal development, and freedom. These fundamental organizing principles were backed up by other measures. For example, to increase motivation Kolind introduced an employee stock program, in which shop floor employees were invited to invest up to $6.000 \mathrm{Dkr}$ (roughly $800 \mathrm{USD}$ ) and managers could invest up to $50.000 \mathrm{Dkr}$ (roughly 7.500 USD). Although these investments may seem relatively small, in Kolind's view they were sufficiently large to significantly matter for the financial affairs of individual employees; therefore, they would have beneficial incentive effects. More than half of the employees made these investments.

The implementation of the spaghetti organization had quick and strong performance effects (Peters 1992, Poulsen 1993). Improved performance in terms of the use and production of knowledge was almost immediate, resulting in a string of remarkable innovations during the 1990s (Verona and Ravasi 1999, Ravasi and Verona 2000). Improved growth and financial performance followed somewhat later (see Table 1$).^{7}$

With respect to improvements in the use of knowledge, the spaghetti organization allowed significant 
NICOLAI J. FOSS Selective Intervention and Internal Hybrids

Table 1 Oticon Financial and Technological Performance

\begin{tabular}{|c|c|c|c|c|c|c|c|c|c|c|c|c|}
\hline & 1988 & 1989 & 1990 & 1991 & 1992 & 1993 & 1994 & 1995 & 1996 & 1997 & 1998 & 1999 \\
\hline Net rev. (mio. Dkr) & 423.8 & 449.6 & 455.4 & 476.5 & 538.8 & 661.3 & 750.3 & 940.2 & $1,087.3$ & $1,413.4$ & $1,613.1$ & $1,884.3$ \\
\hline Profit mg. (\%) & 1.6 & 8 & 3.7 & 1.8 & 5.8 & 13.1 & 17.9 & 12.4 & 12.8 & 13.8 & 15.4 & 17.9 \\
\hline RoE (\%) & -8.5 & 11.6 & 9.4 & -1.5 & 7.2 & 37 & 37.9 & 25.9 & 24.3 & 30.6 & 35.7 & 53.8 \\
\hline Product innovation & & & & Multifocus & Personic & $\begin{array}{l}\text { Oticon } \\
4 \text { kids }\end{array}$ & Noah & Microfocus & Digifocus & $\begin{array}{c}\text { Spin-off } \\
\text { innovations } \\
\text { of digifocus }\end{array}$ & $\begin{array}{l}\text { Spin-off } \\
\text { innovations } \\
\text { of digifocus }\end{array}$ & $\begin{array}{c}\text { Ergo swift } \\
\text { digifocus } \\
\text { // }\end{array}$ \\
\hline
\end{tabular}

Note. Sources: Ravasi and Verona (2000), Annual Reports of Oticon A/S, and William Demant Holding A/S

shelved projects to be revitalized. For example, it was realized that Oticon already had embarked upon development projects for in-the-ear hearing aids as far back as 1979. These projects provided essential inputs into many of the product innovations that Oticon launched during the 1990s. Another effect of the spaghetti organization was that product development time was reduced by $50 \%$. In 1993, half of Oticon's sales stemmed from products introduced in 1993, 1992, and 1991. A total of 15 new products had been introduced since the implementation of the new organization, whereas none had been introduced in the last years of the earlier organization.

A recurring theme in academic treatments of the Oticon spaghetti organization (Morsing 1995, Verona and Ravasi 1999, Ravasi and Verona 2000) is that an important cause of the observed increase in Oticon's innovativeness was the introduction of "structural ambiguity"- that is, the deliberate engineering of freedom and ambiguity in the role system and in the authority structure by means of the introduction of a radical project organization. This condition facilitated the efficient and speedy integration and production of knowledge, resulting in the observed improvement of Oticon innovativeness in the 1990s. This interpretation fails, however, to explain why the spaghetti organization was gradually abandoned from about 1996 in favor of a more traditional matrix organization. It also fails to account for the possible costs of the spaghetti organization. The following section presents a complementary interpretation, based mainly on organizational economics.

\section{The Spaghetti Organization as an Internal Hybrid}

A striking aspect of the spaghetti organization is the prevalence of the market metaphor in the commentaries on the new form by both insiders and outsiders (Peters 1992, Lyregaard 1993, LaBarre 1996). ${ }^{8}$ The spaghetti organization may indeed be interpreted as a radical internal hybrid, because the organization was strongly infused with elements characteristic of market exchange (see Table 2). Although there was no attempt to price internal services in the spaghetti organization and Oticon employees did not become legally independent suppliers of labor services, in many other relevant dimensions Oticon was more like a market than a traditional hierarchical firm. Thus, employees (particularly project leaders) were given many and quite far-reaching decisionmaking rights. Development projects could be initiated by, in principle, any employee, just like entrepreneurs in a market setting, although these projects had to pass not the market test, but the test of receiving approval from the Projects and Products Committee. Project groups were self-organizing in much the same way that, for example, partnerships are self-organizing. The setting of salaries was decentralized to project leaders, acting like independent entrepreneurs (Business Intelligence 1993). Incentives became more high-powered (i.e., efforts and rewards were more closely tied together) as performance

Table 2 Market Organization and the Spaghetti Simulation

\begin{tabular}{cc} 
Market Organization & The Spaghetti Organization \\
\hline $\begin{array}{c}\text { Allocation by means of pricing } \\
\text { pegal independence between }\end{array}$ & $\begin{array}{c}\text { Transfer prices not used } \\
\text { Employment contracts } \\
\text { Freedom of contract }\end{array}$ \\
$\begin{array}{cc}\text { (employment law) } \\
\text { Approximated by delegating } \\
\text { rights to suggest and join } \\
\text { projects }\end{array}$ \\
High-powered incentives & Variable pay; initially based on \\
& objective input and output \\
& measures \\
Dispersed residual claimancy & Employee stock schemes \\
Dispersed decision rights & Very widespread delegation of \\
& rights \\
Dispersed ultimate decision & Concentrated ultimate deci- \\
rights (dispersed formal & sion rights (concentrated \\
authority) & formal authority) \\
Resource allocation decen- & Local entrepreneurship very \\
tralized and strongly influ- & strongly encouraged \\
enced by local entrepre- & Projects approval easily \\
neurship & obtained \\
Strong autonomous adaptation & Secured through extensive \\
properties & delegation of decision \\
& rights \\
\hline
\end{tabular}


pay was increasingly used and as the employee stock ownership program was introduced, thus mimicking the superior incentive properties of the market. Most hierarchical levels were eliminated and formal titles done away with, etc., mimicking the nonhierarchical nature of the market. In sum, market organization was indeed emulated in a number of dimensions.

As a general matter, the attraction of infusing hierarchical forms with elements of market control is that some of the basic advantages of the hierarchy, such as the superior ability to perform coordinated adaptation to disturbances (Williamson 1996), build specialized social capital (Nahapiet and Ghoshal 1999), and share knowledge (Osterloh and Frey 2000), can be combined with the superior incentive properties of the market (Williamson 1996) and its superior flexibility with respect to autonomous adaptation (Hayek 1945, Williamson 1996). Along similar lines, Kolind explicitly saw the spaghetti organization as combining the superior abilities of a hierarchy to build knowledge-sharing environments and foster a cooperative spirit with the flexibility and creativity of a market-like project organization (Kolind 1994).

\section{The Structure of Rights in the Spaghetti Organization}

Organizational economics suggests that understanding the costs and benefits of any organizational form requires examining the structure of decision and income rights in the relevant form (Fama and Jensen 1983; Jensen and Meckling 1992; Hart 1995; Williamson 1996; Barzel 1997; Baker et al. 1999, 2002; Holmström 1999). The benefits and the costs of the spaghetti organization can be comprehended through this lens. The remaining part of this section concentrates on the benefit side.

Centralized decision-making systems, particularly large ones, have well-known difficulties with respect to mobilizing and efficiently utilizing important "sticky" knowledge (von Hippel 1994) such as the precise characteristics of specific processes, employees, machines, or customer preferences (Jensen and Wruck 1994). They therefore often also have difficulties combining such knowledge into new products and processes (Laursen and Foss 2002). As Hayek (1945) explained, the main problem is that much of this knowledge is transitory, fleeting, and/or tacit, and therefore costly to articulate and transfer to a (corporate) center. Markets have advantages relative to pure hierarchies with respect to utilizing such knowledge, particularly when it is not required to utilize the relevant knowledge in conjunction with other knowledge sets (where a hierarchy may have comparative advantages).${ }^{10}$ Thus, markets economize on the costs of transferring knowledge by allocating decision rights to those who possess the relevant knowledge, rather than the other way around (Hayek 1945, Jensen and Meckling 1992). Rights will move towards the agents who place the highest valuation on those rights. Since these agents become residual claimants, effective use will be made of the rights they acquire. From this perspective, internal hybrids are fundamentally attempts to mimic, inside the hierarchy, the decentralization of decision and income rights that characterizes the market in an attempt to improve the efficiency of processes of discovering, creating, and using knowledge. ${ }^{10}$

The spaghetti organization may be understood through this lens, that is, as a hybrid organizational design that aimed at improving the colocation of knowledge and rights through extensive delegation, and backed up this delegation of decision rights by giving employees more income rights. By giving project teams extensive decision rights, requiring that ideas for projects be made public, and ensuring that project teams possessed the necessary complementary skills for a particular marketing, research, or development task, the spaghetti organization stimulated a colocation of decision rights with knowledge. High-powered incentives were provided in an attempt to make sure that efficient use was made of those rights. This improved the use of existing knowledge (cf. the revitalization of "forgotten" projects) and eased the combination of knowledge in the production of new knowledge.

However, Oticon's use of "free market forces" (Lyregaard 1993) was fundamentally a simulation, because the allocation of decision rights in that organization (as in any firm) remained in important respects different from the allocation that characterizes market organization. In contrast to markets, firms cannot concentrate income rights (i.e., residual claimancy) and decision rights to the same extent, in the same hands. An agency problem results from this separation. Many of the elements of the spaghetti organization may be seen as responses to this fundamental agency problem, most obviously the increased use of high-powered incentives. Consider also the rights to allocate resources to a particular project. These may be broken down into groups of decision-making rights, namely rights to (1) initiate projects, (2) ratify projects, (3) implement projects, and (4) monitor and evaluate projects (cf. Fama and Jensen 1983). The efficiency of decision-making processes in project-based firms rests on the allocation and exercise of such rights. For reasons of efficiency, firms usually do not concentrate these rights in the same hands; rather, initiation and implementation rights may be controlled 
by one person (or team), while ratification and monitoring rights are controlled by other persons, usually hierarchical superiors. ${ }^{11}$

This allocation of decision rights was characteristic of the spaghetti organization. Whereas anybody could initiate a project, projects had to be evaluated by the Products and Projects Committee that was staffed by Kolind, the development manager, the marketing manager, and the support manager. The Committee either rejected or approved of the project. The only formal criteria for getting a project accepted were that the relevant project relate to the business areas of Oticon and yield a positive return over a three-year period and with a discount rate of $30 \%$. Apparently, the Products and Projects Committee did not control the use of corporate resources by means of controlling the budgets of individual projects at the project ratification stage. In particular, the use of human resources-the main input category-across projects was not monitored. The rights to implement a project following approval included the right to hire employees in open competition with other projects (Eskerod 1998). Operating projects would meet every third month with the Products and Projects Committee, or a representative thereof, for project evaluation (i.e., monitoring).

The fact that the Projects and Products Committee could veto a project ex ante suggests that it was the real holder of power in Oticon. Frequent intervention on the part of the Committee ex post project approval confirms this (Eskerod 1998). Thus, it became increasingly clear that the Committee could at any time halt, change, or even close projects. This kind of intervention took place frequently. The Projects and Products Committee's exercise of their ultimate decision rights may be seen as simply reflecting the separation discussed above between decision management (i.e., initiation, implementation, and daily project management) and decision control (i.e., project evaluation and monitoring). ${ }^{12}$ However, this separation does not logically imply the kind of ex post intervention that the Committee engaged in. For example, one may imagine that the relevant rights might be allocated so precisely and with so much foresight that there are no incentives to intervene ex post, as in the case of a very detailed contract between two legally independent firms. However, the way in which the Projects and Products Committee exercised their ultimate decision rights is more akin to reneging on a contract, perhaps even to performing a "hold-up" (Williamson 1996). Thus, the Committee effectively reneged in implicit contracts with the projects as the efforts of project became, in the eyes of the Committee, superfluous (e.g., because of new technological developments), moved in unforeseen directions, or were revealed to have been founded on ill-conceived ideas. In turn, this exercise of ultimate control rights caused unforeseen incentive problems, as will be discussed later.

\section{Organizational Complementarities}

An interesting aspect of the spaghetti organization is that an explicit logic of complementarity was present in the reasoning of its main designer. Observed Kolind: "It was not strictly necessary to do all these things at the same time, but we opined that with a simultaneous implementation of the changes [in organizational elements] ... they would reinforce each other" (in Mandag Morgen 1993, p. 17; my translation). Complementarities between elements of an organizational form exist when increasing the level of one element increases the marginal return from increasing the level of all remaining elements (Milgrom and Roberts 1990, Hemmer 1995, Zenger 2002). Loosely, when complementarity obtains, the dynamics of organizational elements imply that they move together. Changing one element in an isolated way is likely to set in motion (possibly unforeseen) processes of change in other elements because the system will grope towards an equilibrium where all elements have changed (Zenger 2002). The process of groping may be associated with serious inefficiencies. Therefore, organizational change initiatives should "get the complementarities right."

Apparently, the spaghetti organization did exactly this. Thus, the change in the rights structure of Oticon was such that decision rights changed in a way that was complementary to the change in income rights; specifically, widespread delegation of decision rights was accompanied by making incentives more high powered through performance pay and employee ownership. In turn, the change in incentives was backed up by complementary changes in measurement systems. Thus, a performance evaluation system was implemented in which employee performance was measured in three to eight different dimensions (depending on the type of employee) and pay was made dependent on these measures (Poulsen 1993).

Other initiatives may also seen to be complementary to the increase in the delegation of rights in the spaghetti organization. For example, the open office landscape and the strategically placed coffee bars and staircases were complementary to rights delegation in terms of utilizing and building knowledge because they helped foster the knowledge exchange that gave rise to new ideas for project teams. With respect to the moral hazard problem introduced by delegating rights, the new 
much-more information-rich environment was also complementary to this delegation, because it helped to build reputational effects (cf., Eskerod 1997, 1998) and eased mutual monitoring among employees, keeping agency problems at bay. Kolind's (1990) strong emphasis on building culture in the new organization may be seen in a similar light: Influencing preferences through the building of shared values became an important activity in the spaghetti organization, because its strong delegation of rights introduced both problems of coordinating independently made decisions (Miller 1992) and agency problems, problems that are reduced as preferences become more homogeneous. The complementary nature of these organizational elements also explains the speed and toughness with which Kolind managed the transition from the old organization. ${ }^{13}$ This is because it is usually inefficient to change systems of complementary elements in an incremental manner; transition between such systems should normally be accomplished in a "big bang" manner (cf., Dewatripont and Roland 1995).

\section{Spaghetti and Beyond}

\section{Retreating from Spaghetti}

In his account of the spaghetti organization, Gould (1994, p. 470) noted that “... Lars Kolind's vision was the right one for Oticon. In any case, one thing was certain: there could be no turning back." However, beginning in 1996, a considerable "turning back" actually began: Oticon embarked upon a partial abandonment of the spaghetti organization and gradually adopted a more traditional matrix structure. In 1996, Oticon headquarters was divided into three "business teams" that are essentially new administrative layers. In addition to the business teams, a "Competence Center" was set up. This unit is in charge of all projects and their financing and of an operational group that controls administration, IT, logistics, sales, and exports. It is one of the successors to the now abandoned Projects and Products Committee. However, its style of managing projects is very different. In particular, care is taken to avoid the kind of intervention in already-approved-of projects that characterized the Products and Projects Committee. The team leaders and the head of the Competence Center comprise, together with the CEO, the "development group," which may be seen as a second successor to the Products and Projects Committee of the original spaghetti organization. The development group, which essentially is the senior executive group, is in charge of overall strategy making. It is also the unit from which most of the initiative with respect to starting new projects comes. Many of the decision-making rights earlier held by project leaders have now been concentrated in the hands of the Competence Center, or the managers of the business teams. For example, project leaders' rights to negotiate salaries have been constrained. Project leaders are appointed by the Competence Center, so that the right to be a project leader is not something that one grabs, as under the spaghetti organization. Although the multijob concept is still present, the extreme forms that characterized the spaghetti organization are not.

To sum up, recent changes of administrative systems at Oticon have amounted to a break with the radical bottom-up approach that characterized the original spaghetti structure. Thus, although Oticon is still characterized by considerable decentralization and delegation of rights, many of the crucial elements of the spaghetti organization have been left.

\section{Searching for Possible Causes of the Partial Failure of the Spaghetti Experiment}

Although the spaghetti organization at first inspection seems to have been a particularly well-crafted internal hybrid, closer inspection may reveal design mistakes that caused its abandonment. An organizational economics perspective suggests that a number of candidates for design mistakes be discussed. They may be grouped into problems of allocating competence, eliminating tournaments, sacrificing specialization advantages, coordination, knowledge sharing, and influence activities. ${ }^{14}$ They are discussed in the following.

Allocating Competence. Demsetz (1988) and Casson (1994) argue that firms are hierarchical because this is an efficient way of utilizing different yet complementary knowledge; direction may be less costly than instruction or joint decision making. When this is the case, those with more decisive knowledge should direct those with less decisive knowledge. Thus, the hierarchy is an efficient method of allocating competence. The spaghetti organization eliminated most hierarchical levels. Thus, the extent to which hierarchy could be used as a sorting mechanism for allocating skills was much smaller in the spaghetti organization. For example, the delegation of project initiation rights implied that competent and less competent employees had the same rights to initiate projects and get a hearing before the Projects and Products Committee. Knowledge-based inefficiencies may have resulted that may have been avoided in a traditional hierarchy.

However, this explanation implicitly asserts that managers are, on average, more knowledgeable with respect to what actions subordinate employees should optimally 
take than these employees are themselves. If this is not the case, bottom-up selection processes may sort better than hierarchical processes. In fact, the spaghetti organization was (at least in the official rhetoric) very much founded on the notion that bottom-up processes would select more efficiently than hierarchical processes. Hierarchical superiors may be more knowledgeable about which actions should be optimally taken by subordinates when there are strong complementarities between the actions of subordinates, and hierarchical superiors possess superior information about these complementarities and/or they possess private information about which states of the world have been realized (Foss and Foss 2002). To be sure, complementarities between subordinates' actions and knowledge sets obtained in the spaghetti organization. However, the purpose of the spontaneous, marketlike, bottom-up processes was exactly to discover and utilize such complementaritiessomething that the earlier hierarchical organization had not been capable of. Thus, it seems unlikely that abolishing the hierarchy in Oticon led to serious inefficiencies related to the allocation of competence.

Eliminating Tournaments. From an incentive perspective, the extremely flat spaghetti organization implied that one particular incentive instrument was no longer available to the organization: Hierarchical job ladders could no longer function as incentive mechanisms in their own rights because the spaghetti organization essentially abolished what agency theorists call "tournaments" between managers (Lazear 1995). Promotion was no longer a "prize" that could be obtained through expending effort. However, while the spaghetti organization may have eliminated this particular incentive instrument, it introduced a number of new incentive instruments, such as performance pay. From the point of view of individual employees, these new instruments may have had stronger motivational effects than tournaments because they were less open to political manipulation. Thus, the sacrifice of tournaments as an incentive instrument may not have been a major problem.

Sacrificing Specialization Advantages. A key component of the spaghetti organization was the multijob concept which implied that each employee was (1) encouraged to develop skills outside her present skill portfolio and (2) free to join projects as she saw fit. Much work on Oticon has treated the multijob concept as a strong stimulus to knowledge exchange and integration (e.g., Verona and Ravasi 1999, Ravasi and Verona 2000), presumably quite rightly so. However, the concept may also have introduced distinct costs, most obviously the sacrifice of specialization advantages that it would seem to imply. However, there are indications that this was actually not the case. For example, an Oticon engineer may have been encouraged to develop English writing skills, which would place him in a better position to undertake technical translation relevant to his project, and do so in a more informed way than a professional translator would be capable of. Thus, this aspect of the multijob concept may have led to beneficial exploitation of complementarities between different skills.

Problems of Coordination. However, there is strong evidence that the second part of the multijob concept, the freedom to join projects, had significant costs. ${ }^{15}$ Nobody kept track of the total time that employees spent on projects. ${ }^{16}$ Moreover, project leaders were free to try to attract those who worked on competing projects, and in many cases they succeeded in doing so. This was a consequence of the explicit aim to emulate the market, but the effect was that it was hard to commit employees to projects and to ensure an efficient allocation of attention to projects (Gifford 1992). This led to severe coordination problems because project leaders had no guarantee that they could actually carry a project to its end. Moreover, many employees joined more projects than their time resources possibly allowed for, creating problems of coordinating schedules and work hours. The Products and Projects Committee had no routines for dealing with these problems. Apparently, reputation mechanisms were not sufficient for coping with them either. It would perhaps seem that these problems could have been reduced by simply prohibiting employees from working on more than, say, two projects that could not add up to more than $100 \%$ of the employee's total work hours. ${ }^{17}$ Establishing such controls in the original spaghetti organization would, however, have run against the official rhetoric of autonomy, empowerment, and delegation. Alternatively, monitoring systems might have been refined to control dimensions of employee behavior that related to their attention and work allocation across the projects in which they participated, so as to reduce coordination problems. However, the very elaborate monitoring system that was implemented together with the spaghetti organization and that involved the construction of objective measures on half a dozen aspects of employee behavior (Poulsen 1993) appears to have been quickly and tacitly shelved and substituted with a simpler system that relied much more on subjective performance assessment (Business Intelligence 1993). This suggests that the problem with monitoring systems under the original spaghetti organization rather was that they were already too complex and costly to administer in practice. 
Problems of Knowledge Sharing. The multijob concept promoted knowledge sharing and, in turn, knowledge creation. However, there is evidence (Eskerod 1997, 1998) that knowledge sharing was not always spontaneous and uninhibited. In fact, in some cases, knowledge tended to be held back within projects, because of the widespread and correct perception that projects were essentially in competition over corporate resources. Thus, by stressing so strongly a marketlike competitive ethos and by making incentive systems more "high-powered" (Williamson 1996) than they had been under the old organization, the spaghetti organization to some extent worked against its stated purposes. The organization's measurement and reward systems apparently could not fully cope with these problems. It may be questioned how significant this problem was. The impressive innovation record of Oticon in the 1990s indicates that the firm's creation of knowledge may not have been significantly harmed by the competitive relations existing within the spaghetti organization. Still, the relevant question is whether the knowledge-sharing environment could have been better designed. Knowledge sharing is not necessarily best stimulated by a kind of project organization that simulates competitive markets. To the extent that knowledge sharing is a hard-tomeasure performance variable, employees are likely to put less of an emphasis on this (Holmström and Milgrom 1991). Upon realizing this, resorting to lower-powered incentives is likely (Holmström 1999). This corresponds to what has happened in Otcion. Although the performance measurement systems in Oticon now includes attempts to measure employees' contribution to knowledge sharing, it is also the case that the strong competitive ethos which characterized the spaghetti organization has been significantly dampened in the successor form.

Influence Activities. Influence activities are activities that subordinates engage in when they influence hierarchical superiors to make decisions that are in their own interests, rather than in the organization's (Milgrom 1988, Argyres and Mui 2000). Resources expended on influence activities are, from the point of view of the organization, waste. It is arguable that it is relatively more difficult under an organization such as the spaghetti organization to protect against influence activities. This is because everybody has, in principle, direct access to the management team. A comparative advantage of the traditional, hierarchical, and rule-governed organization is exactly that it may be better at protecting itself against influence activities because access to those who hold ultimate decision rights is more difficult. In fact, the spaghetti organization which actively stimulated competition between project groups for the approval of the only relevant "hierarchical superior" left, namely the Projects and Products Committee, did produce such influence activities (Eskerod 1998). In contrast, under the hierarchical form existing prior to the spaghetti organization, such activities had been much less prevalent because of the aloof management style of the old management (Poulsen 1993). Personal relations to those who staffed the Committee became paramount for having a project ratified by the Committee. As Eskerod (1998, p. 80) observed:

Part of being a project group may be lobbying in the PPC trying to obtain a high priority status by influencing the PPC members. The reason for doing this is that a high priority project is regarded as a very attractive place for the employees,

because the management sees this project as important.

It is, however, not clear from the existing empirical studies of the spaghetti organization that this was perceived of as a serious problem in the organization-for example, whether it resulted in obviously unimportant projects being approved of by the Committee. Rather, it was taken as an unavoidable, and relatively small, cost of the spaghetti organization. ${ }^{18}$

To sum up, the search for the causes of the partial abandonment of the spaghetti organization so far seems to lead only to inefficiencies stemming from the lack of well-functioning project management routines on the part of Products and Projects Committee being a serious problem. However, handling this problem did not necessarily require a major organizational change. Still, the many possible small liabilities of the spaghetti organization (problems of knowledge being held back in projects, influence activities, etc.) may together have added up to significant costs that could be reduced by adopting a more structured organizational form (Børsens Nyhedsmagasin 1999, interview with Henrik Holck on June 2000). Moreover, there is one fundamental problem left that was clearly present in the spaghetti organization, and which is a strong candidate for explaining the abandonment of that organizational form.

\section{The Problem of Selective Intervention}

Although infusing hierarchical forms with elements of market control seems attractive, crafting and implementing such internal hybrids is a highly complicated problem. One reason is a fundamental incentive problem that plagues all hierarchies, but is arguably particularly prevalent in the kind of very flat organizations of which the Oticon spaghetti organization is an example. An early statement of the nature of this problem can be found in the comparative systems literature in 
economics, that is, the literature taken up with the economic differences between capitalist and socialist systems. Thus, Mises (1949, p. 709) argued that there are fundamental problems involved in "playing market" inside hierarchies. ${ }^{19}$ Specifically, schemes for a socialist market economy would not work because the concentration of ultimate decision-making rights and responsibilities (i.e., ownership) in the hands of a central planning board would dilute the incentives of managers. Thus, while planning authorities could delegate rights to make production and investment decisions to managers, these rights would be inefficiently used. First, because managers could always be overruled by the planning authorities, they were not likely to take a long view, notably in their investment decisions. Second, because managers were not the ultimate owners, they were not the full residual claimants of their decisions and, hence, would not make efficient decisions.

Later research has clarified that (1) handling the problem requires that the planning authorities can credibly commit to a noninterference policy, and (2) the problem goes beyond the comparative systems context. It is latent (or manifest) in all relations between "rulers" and "ruled" (North 1990, Miller 1992, Williamson 1996, Foss and Foss 2002). The problem arises from the fact that it is hard for the ruler to commit to a noninterference policy because reneging on a promise to delegate will in many cases be extremely tempting, and those to whom rights are delegated will anticipate this. Loss of motivation results. The problem is not unknown in organizational studies, (e.g., Vancil and Buddrus 1979, p. 65). In particular, Williamson's (1996) concept of the "impossibility of selective intervention" is highly relevant. He describes it as

\footnotetext{
... a variant on the theme, "Why aren't more degrees of freedom always better than less?" In the context of firm and market organization, the puzzle is, "Why can't a large firm do everything that a collection of small firms can and more." By merely replicating the market the firm can do no worse than the market. And if the firm can intervene selectively (namely, intervene always but only when expected net gains can be projected), then the firm will sometimes do better. Taken together, the firm will do at least as well as, and will sometimes do better than, the market (1996, p. 150).
}

Williamson directly argues that (efficient) selective intervention of this kind is "impossible." Incentives are diluted, because the option to intervene "... can be exercised both for good cause (to support expected net gains) and for bad (to support the subgoals of the intervenor)" (Williamson 1996, pp. 150-151). Promises to only intervene for good cause can never be credible, Williamson argues, because they are not enforceable in a court of law. The wider implication of this reasoning is that because decision rights cannot be delegated in a court-enforceable manner inside firms (i.e., are not contractible), authority can only reside at the top. Authority cannot be delegated, even informally, because any attempt to do this will run into the problem of the impossibility of selective intervention. One would therefore expect to see little use of delegation. Given that delegation is clearly a viable and widespread organizational practice, this suggests that this implication is going too far.

In fact, it is conceivable that the "intervenor" may credibly commit to not intervene in such a way that the "subgoals of the intervenor" are promoted. The logic may be stated in the following way (cf. Baker et al. 1999). Assume that a subordinate initiates a project. ${ }^{20}$ Assume further that the manager has information that is necessary to perform an assessment of the project, but that he decides upfront to ratify any project that the subordinate proposes. Effectively, this amounts to full informal delegation of the rights to initiate and ratify projects- "informal," because the formal right to ratify is still in the hands of the manager and because that right cannot be allocated to the subordinate through a courtenforceable contract (cf. Williamson 1996). Because the subordinate values being given freedom-she is partly a residual claimant on the outcomes of his activities - this will induce more effort in searching for new projects (Aghion and Tirole 1997, Foss and Foss 2002). To the organization, the expected benefits of these increased efforts may be larger than the expected costs from the bad projects that the manager has to ratify. However, a problem arises when the manager has information about the state of a project ("bad" or "good"), because he may then be tempted to renege on a promise to delegate decision authority, that is, intervene in a "selective" manner. If he overrules the subordinate, the latter will lose trust in him, holding back on effort. Clearly, in such a game a number of equilibria, each one characterized by different combinations of employee trust and managerial intervention, are feasible. What determines the particular equilibrium that will emerge is the discount rate of the manager, the specific trigger strategy followed by the subordinate (e.g., will he lose trust in the manager for all future periods if he is overruled, or will he be more forebearing?), and how much the manager values his reputation for not reneging relative to the benefits of reneging on a bad project (Baker et al. 1999).

All of the above build on standard economics assumptions on motivation and cognition: Employees are motivated solely by being able to share in the outcomes of their activities, and managerial intervention decreases 
motivation because it means that the expected gain of putting effort into a project diminishes. Including richer motivational and cognitive concerns aggravates the problem of selective intervention. As argued in an extensive literature in psychology (summarized in Frey 1997), people are also likely to be intrinsically motivated. Such motivation may be sustained by psychological contracts that involve loyalties and emotional ties (Brockner et al. 1992, Robinson and Morrison 1995, Osterloh and Frey 2000, p. 541). Managerial intervention, particularly when it is perceived to be essentially arbitrary, may break such contracts and harms intrinsic motivation (Robinson and Rousseau 1994). Other parts of psychological research (summarized in Bazerman 1994) suggest other ways in which the problem of selective intervention may be aggravated in practice. Thus, robust findings in experimental psychology show the presence of a systematic overconfidence bias in judgment; that is, people tend to trust their own judgments more than is "objectively" warranted. Managers are not exceptions to this bias, perhaps quite the contrary. The presence of the overconfidence bias in the judgments that underlie managerial decision making is likely to aggravate the problem of selective intervention, because it produces additional meddling in subordinates' decisions (Nickerson and Zenger 2001, p. 15).

\section{Selective Intervention in Oticon}

It is arguable that the main reason that the spaghetti organization was changed into a more hierarchical organization has to do with the kind of incentive and motivational problems described above. The official Oticon rhetoric, stressing bottom-up processes in a flexible, marketlike, and essentially self-organizing system with substantial autonomy and a management team (i.e., the Projects and Products Committee) that acted as little more than facilitator (Kolind 1990, Lyregaard 1993), became increasingly at odds with the frequent selective intervention that was undertaken by the Projects and Products Committee. ${ }^{21}$ The need for selective intervention was rationalized by an external observer in the following terms:

\footnotetext{
... PPC [the Products and Projects Committee] does not make general written plans, which are accessible to the rest of the organization... if this were done, plans would have to be adjusted or remade in an ever-continuing process, because the old plans had become outdated (Eskerod 1998, p. 80).
}

This entirely ad hoc approach was taken by the Products and Projects Committee to be an unavoidable feature of a flexible, project-oriented organization (Eskerod
1998, p. 89). However, it was also a direct signal to employees that the "contract" between any project and the Products and Projects Committee was very incomplete (Williamson 1996), and that the Committee might at any time exercise its ultimate control rights for the purpose of intervening in projects. This produced diluted incentives and badly harmed motivation (as documented at length by Eskerod 1997, 1998). Accumulating frustration finally resulted in a major meeting in 1995, which marked the beginning of the retreat from the spaghetti organization. At the meeting employees dramatically expressed their concerns about the contrast between on the one hand, the Oticon value base, including the strong rhetoric of delegation, and on the other hand, the way in which the company was actually managed. Frustration that projects were interrupted in seemingly arbitrary ways and that the organization was far better at generating projects than at completing them was explicitly voiced.

The preceding discussion suggests that a fundamental problem in the spaghetti organization was that Kolind and the Products and Projects Committee never committed to a policy of not intervening selectively; neither, apparently, did they intend to do so or even see any rationale in it. Kolind's view appears to have been that in important respects and in many situations, he and the Products and Projects Committee would possess accurate knowledge about the true commercial and technical possibilities of a given project, and that efficient utilization of corporate resources dictated intervening in, and sometimes closing down, projects. However, that view clashed on a basic level with the rhetoric of widespread delegation of decision rights, leading to the demise of the spaghetti organization and the adoption of the present more-structured matrix organization.

In principle, Kolind and the Products and Projects Committee could have committed to a policy of noninterference from the beginning, rather than acting on the belief that organizational flexibility required that they selectively intervene in projects. Conceivably, this might have made this radical internal hybrid viable. However, even if Kolind and the Products and Projects Committee had announced initially that they would refrain from selective intervention, there are reasons why this commitment may not have been sustainable in the longer run. Thus, it was increasingly clear that the elaborate system of measures that was initially installed was inadequate. It did not capture important dimensions of behavior (e.g., employees' contribution to knowledge sharing) and it may have contributed to some projects holding back knowledge. Rather than trying to refine the system further, it was abandoned. ${ }^{22}$ However, the 
implication was that management could no longer take place solely through incentives (following initial ratification of projects). The employee stock ownership program was arguably not sufficiently high powered to truly motivate, and did not confer sufficient decision rights to halt the practice of selective intervention to employees. The implication was that Kolind and the Products and Projects Committee had to engage in much more monitoring of the projects. Doing this without compromising team autonomy and harming motivation was unlikely.

\section{The New Organization}

A notable feature of the present Oticon organization lies in its much more consistent approach towards projects. Organizational expectations are that priorities do not change in the rapid and erratic manner that characterized the original spaghetti organization, and that employees can be much more sure that the projects they are working on are taken all the way to the end. In the new organization, projects are rarely stopped or abandoned, and there is an explicitly stated policy of sticking to ratified projects. Two reasons are given for this. First, projects are more carefully examined with respect to technical feasibility and commercial implications. An aspect of this is that the Competence Center now much more actively puts forward project ideas and contacts potential project leaders, rather than relying on the bottomup approach that characterized the original spaghetti organization. Thus, hierarchical selection has to some extent substituted for selection performed by bottomup processes. Second, the wish to avoid harming motivation (i.e., diluting incentives) by overruling ongoing projects is strongly stressed. The management team has openly announced this policy, and has made it credible by (1) consistently sticking to it and (2) researching project ideas carefully ex ante so that employees' perceived probability that intervention will occur is low. Some reasons why a more traditional hierarchy may be better at making such commitment credible is discussed in the following section.

\section{Discussion: Implications for Internal Hybrids}

Proponents of internal hybrids argue that their advantage lies in the ability to integrate the virtues of more conventional organizational forms (Miles et al. 1997). Specifically, internal hybrids combine the ability to achieve efficiencies through specialization that characterizes the functional form with the relative independence that can be granted in a divisional form, and the ability to transfer resources and capabilities across division and business unit boundaries that characterize the matrix organization (e.g., Miles and Snow 1992). The designers of the Oticon spaghetti organization invoked strikingly similar arguments (Kolind 1990, 1994; Lyregaard 1993). This suggests that broader lessons with respect to the efficient design of internal hybrids may emerge from the Oticon experience.

\section{Getting Complementarities Right}

A basic proposition in much of organization theory is that for reasons of efficiency, organizational forms are aligned with environmental conditions, strategies, and exchange conditions in a systematic and discriminating manner (Thompson 1967, Meyer et al. 1993, Williamson 1996, Nickerson and Zenger 2000). Thus, Zenger (2002, p. 80) argues that many attempts to infuse hierarchies with elements of market control break with this basic proposition and often "... violate patterns of complementarity that support traditional hierarchy as an organizational form.” For example, managers implement new structures without new performance measures and new pay systems, or they implement new pay systems without developing new performance measures. This results in unstable, possibly inefficient, hybrid forms. In contrast, viable internal hybrids are characterized by organizational elements clustering in certain characteristic, complementary combinations, just as in the case of markets and hierarchies (Williamson 1996).

Did the spaghetti organization get the complementarities between organizational elements right? On first inspection, it did, as has been argued. However, closer inspection reveals a somewhat different picture. Thus, it may be argued that Oticon did not get the organizational complementarities exactly right, because the kind of radical internal hybrid that was adopted requires that projects be managed almost exclusively through the provision of incentives and ownership (Miles et al. 1997, Zenger 2002). The performance measurement systems in the spaghetti organization were not adequate to support precise performance evaluation. Some relevant performance dimensions (e.g., contribution to knowledge sharing) were not measured at all. Also, the incentive effects of the employee stock ownership program appear to have been limited. Thus, remuneration schemes may not have rested on sufficiently precise and encompassing measures and were not sufficiently high powered to complement the widespread delegation of decision rights in the organization. This fostered a need for selective intervention on the part of Kolind and the Products and Projects Committee that went beyond what would have 
been necessary with better measures of employee performance, and which had the unintended effect that motivation was seriously harmed. This reasoning suggests the following proposition:

PROPOSITION 1. Internal hybrids that violate patterns of complementarity characteristic of this organizational form will be subject to more problems of selective intervention than hybrid forms that get the complementarities right.

A corollary to this proposition is that advances in measurement methods will result in less selective intervention because the measurement of performance is improved so that the moral hazard stemming from the delegation of rights is reduced.

\section{Problems of Intervention and Organizational Form}

The motivational and incentive problems that may emerge from managerial selective intervention are not independent of organizational structure, notably, the number of hierarchical layers in the organization, and therefore the distribution of information and authority in a firm. Arguably, organizations that adopt internal hybrids that amount to drastically reducing the number of hierarchical layers, such as Oticon's spaghetti experiment, are more prone to the problem than more traditional hierarchical firms. There are (at least) three reasons for this.

First, decision rights are more solidly established in a traditional hierarchy, which is associated with welldefined, distinct positions than in a flat, project-based organization where decision rights are more fleeting. Organizational expectations that certain positions come with certain decision rights are very well established, and potentially costly for a top manager to break with through selective intervention. The same kind of organizational expectations are not likely to be established in a flat, project-based organization. Second, a top manager who selectively intervenes in a hierarchical organization risks overruling the whole managerial hierarchy (all those below him), whereas this may be a smaller concern in a flat organization where the CEO may only harm motivation in a specific project team if he overrules that team. Third, information-processing perspectives (Thompson 1967, Galbraith 1974) suggest that the hierarchy is not just a structure of authority, but also one of information. The informational distance between projects and top manager may be increased by having a multilayered hierarchy. This implies that the top manager knows that he is in key dimensions ignorant about the project (Aghion and Tirole 1997). In this case, his incentives to selectively intervene will be small. The preceding arguments suggest the following proposition:
Proposition 2. An internal hybrid form that is organized within a firm with few hierarchical layers will be associated with larger efficiency losses caused by problems of selective intervention than an internal hybrid form that is organized within a firm with more hierarchical layers.

\section{Problems of Intervention and the External Environment}

A key reason why the Products and Projects Committee considered that frequent selective intervention was necessary had to do with the impossibility of making detailed plans for future business development in an industry where unforeseen contingencies (e.g., new technologies) often occurred. This suggests a third proposition:

PROPOSITION 3. There will be more selective intervention in internal hybrid forms that operate in turbulent industries than in internal hybrid forms that operate in tranquil industries.

This proposition may be taken to be the other side of the coin of the transaction cost argument that external hybrids are unstable in "dynamic" industries (Williamson 1996) because in such industries unexpected contingencies that may give rise to holdups are more likely. Along similar lines, the argument underlying Proposition 3 is that in dynamic industries, the implicit contract between teams/projects and management in internal hybrids is likely to be relatively more incomplete than in more tranquil industries. Therefore, management is likely to engage in more selective intervention in an attempt to influence how projects react to unexpected contingencies.

\section{Internal and External Hybrids and Internal and External Markets}

The problem of selective intervention casts a novel light over governance choices between internal and external hybrids and internal and external markets (Poppo 1995). These organizational forms may be seen as rather close substitutes. For example, they may be adopted in order to better exploit local knowledge (Cowen and Parker 1997), or to strengthen incentives, because they make agents residual claimants to a higher degree than is the case in traditional hierarchies. However, whereas internal hybrids/internal markets may suffer from problems stemming from selective intervention, external hybrids/external markets do not suffer from these. Of course, external hybrids and markets may suffer from inefficiencies caused by holdup problems when specific assets are deployed. However, creating competition between suppliers, investing in hostages, having 
some tapered integration, etc., may strongly reduce problems related to holdup. The legal system also constrains the holdup possibility, however imperfectly. In contrast, a solution to the problem of avoiding harmful selective intervention cannot rely on market forces or court-enforceable contracts. The implication is that, on average, external markets and external hybrids are likely to have incentive properties that are superior to those of internal markets and internal hybrids, so that there will be (transaction and production) cost penalties associated with the use of the latter. This results in the following proposition:

Proposition 4. Firms that choose external hybrids (markets) over internal hybrids (markets) will have a cost performance that is superior to those that choose internal hybrids (markets) over external hybrids (markets).

This reasoning may be seen as a variation of a familiar theme of transaction cost economics (Williamson 1996), namely that vertical integration be considered the option of last resort.

\section{Managing Commitment to Not Selectively Intervene} While theory suggests that the problem of committing to not selectively intervene is a tough one, we do seem to observe a substantial amount of delegation in realworld firms. This indicates that it is possible to credibly commit to nonintervention. There are two fundamental methods that managers may use for this purpose. Both essentially tie the hands of a would-be intervenor.

The first one is to commit oneself to being (rationally) ignorant. Thus, a manager may choose not to be informed about a number of critical dimensions in projects. In very hierarchical organizations this may be easy to accomplish because of the large informational distance between topmanagement and projects. A second approach proceeds by managers making it harmful to themselves to selectively intervene. Open announcement of a nonintervention policy, making such policy recorded in company documents, working to install it in corporate culture, etc., all contribute to meeting this aim because it makes the possible clash between the communicated values and managerial interventionist practice extremely sharp, and makes very obvious the break of the explicitly stated psychological contract (Brockner et al. 1992).

\section{The Spaghetti Organization as a Modulation Between Stable Organizational Forms}

Although organizational forms that break with a logic of complementarity may incur penalties in terms of static efficiency (i.e., economizing with transaction costs and costs of production), they may still conceivably yield benefits in terms of dynamic efficiency (i.e., innovativeness). Calls for "chaotic" organization (Peters 1992) often implicitly make such arguments. Organization design needs to consider both types of efficiencies (Ghemawat and Ricart i Costa 1993). An implication is that in an intertemporal perspective, choosing "consistent" configurations of organizational elements may not necessarily maximize the value of the firm. An ingenious argument of this kind has been developed by Nickerson and Zenger (2000). They suggest that considerations of efficiency may require modulating between discrete organizational forms - such as the old hierarchical Oticon organization and the postspaghetti matrix structure-even in response to a stable set of environmental conditions. This is because the steady-state functionality delivered by a discrete organizational form may itself be discrete, and the desired functionality may lie in-between those delivered by the discrete organizational forms. Efficiency gains may then be obtained by modulating between the forms.

If indeed the Oticon spaghetti organization may have incurred inefficiencies with respect to the organization of its administrative systems, it is hard to dispute that it was also a quite innovative organization (cf. Table 1). These benefits may likely have overwhelmed the organizational costs. Although the spaghetti organization was not stable in the presence of the problem of selective intervention, it would still have made sense to choose this form, even if the designers had known it to be inherently unstable. In fact, much of the early discussion of the spaghetti organization made reference to the need to try something entirely new and admittedly chaotic, for the purpose of drastically shaking up the original, bureaucratic organization (Kolind 1990, Peters 1992, Poulsen 1993). This is consistent with Nickerson and Zenger's theory: The spaghetti organization may indeed be an example of modulating between the stable organizational form of the traditional, prespaghetti hierarchy, and the stable matrix organization post the spaghetti. What lends credence to this interpretation is that although the hearing aids industry was technologically quite dynamic in the relevant period (Lotz 1998), it is not possible to identify environmental changes that might have caused the organizational change away from the spaghetti.

\section{Firms and Markets}

The present discussion casts light over the classical issue of what the fundamental differences are between firms and markets, and supports the original Coasian position that the key difference is that markets do not rely on resource allocation by means of authority, whereas 
firms do (Coase 1937). "Authority" is a problematic word because it is often invested with a too-narrow meaning, for example, detailed direction and supervision (Foss and Foss 2002). Ultimately, the meaning of having authority is that one can restrict the decisions of one's subordinate, overrule him, and perhaps fire him. This means that although decision rights may be delegated, we can still trace the chain of authority in a firm, and we will always realize that ultimate decision-making power resides at the top. As this paper has illustrated, all subordinates' decision rights "are loaned, not owned" (Baker et al. 1999, p. 56). Fundamentally, it can never be otherwise. This is because ultimate decision-making rights can only be transferred from bosses to subordinates in one way, namely by transferring ownership (Hart 1995). However, transferring ownership amounts to spinning-off the person to whom ownership is given. It means creating a new firm. It is this fundamental difference in how ownership is allocated that underlies the problem of selective intervention. The analysis in this paper thus makes direct contact with important modern theories of economic organization (Hart 1995, Williamson 1996, Baker et al. 2002) that stress the importance of ownership for the understanding of the nature of firms and firm boundaries.

\section{Conclusions}

To many firms, the adoption of new, hybrid organizational forms is increasingly seen as imperative. However, rather little theoretical and empirical research has treated particularly internal hybrids. This paper has examined a specific experiment with adopting and later strongly modifying a radical internal hybrid in an attempt to identify some possible liabilities of the adoption of such organizational forms. In particular, the focus has been on motivational problems that may be caused by problems of committing to refraining from harmful selective intervention. A main argument was that problems of selective intervention are particularly prevalent in organizations that adopt radical internal hybrids. In contrast, firms with more traditional hierarchical structures better shield themselves from these problems. Managers may commit to nonintervention by means of rationally choosing to be ignorant or by making it harmful to themselves to selectively intervene. Finally, the problem of selective intervention is a prime candidate for understanding the incentive liabilities of hierarchies and internal hybrids vis-à-vis markets or external hybrids.

Although this paper has thus exemplified the interpretive power of organizational economics, admittedly organizational economics only tells a part of the story. From an organizational economics perspective, the spaghetti organization represented a matrix of rights and incentives that are helpful for understanding its liabilities and how these liabilities gave rise to certain organizational dynamics (i.e., the partial abandonment of the spaghetti organization). However, it may indeed also be understood in terms of an attempt to, for example, foster dynamic capabilities (Ravasi and Verona 2000), a perspective that lies outside of organizational economics. Thus, the full story of the Oticon spaghetti experiment requires that more than one perspective be considered. Relatedly, the paper has suggested that organizational economics should consider to a fuller extent psychological insights in motivation and in cognition. While it is possible to tell stories of managerial commitment, selective intervention, and stifled incentives based only on organizational economics, there is little reason to be so narrow. A vast literature on procedural justice in organization, psychological contracts, and (biased) cognition exists, the insights of which may be combined with organizational economics insights in order to further the understanding of problems of managerial commitment, including problems of selective intervention (cf. also Miller 1992, Lindenberg 2000).

\section{Acknowledgments}

The author acknowledges discussion with, and helpful comments from, Kirsten Foss, Robert Gibbons, Anna Grandori, Henrik Holck, Lars Kolind, Kristian Kreiner, Peter Lotz, Volker Mahnke, Peter Maskell, Mette Morsing, two anonymous reviewers, and Senior Editor Axel von Werder, as well as seminar audiences at Copenhagen Business School, the Universität Freiburg, Norges Handelshøyskole, and the University of Pisa on earlier drafts of this paper. All mistakes, errors of interpretation, etc. are solely the responsibility of the author.

\section{Endnotes}

${ }^{1}$ Zenger (2002) argues that much more work exists on external hybrids than on internal hybrids, investigation of the latter being largely confined to work on the multidivisional form. And Poppo (1995, p. 1,845$)$ points out that "[e]mpirical work that examines the differences between internal and external markets are rare.... Theory in this area is also limited."

${ }^{2}$ However, a main purpose of conducting analysis of single cases often is to be able to pose competing explanations for the same set of events (and perhaps to indicate how these explanations may be applied to other situations) (Yin 1989). Moreover, basic considerations of internal validity dictate that alternative explanations be considered. However, while I shall indeed make reference to and discuss other possible explanations of some of the relevant events (e.g., ideas from motivation theory and information processing theory), the main emphasis is on developing one specific interpretation. While an eclectic, multipleperspective approach may be superior in the abstract, more insight may arguably be provided in the concrete by pursuing, in a relatively narrow fashion, one specific interpretation and explore the limits of this interpretation. 
${ }^{3}$ See Lotz (1998) for a careful analysis of the hearing aids industry, with particular emphasis on patterns of innovation. The history of Oticon prior to the introduction of the spaghetti organization is extensively covered in Poulsen (1993) and Morsing (1995), and, more briefly, in Gould (1994) and Lovas and Ghoshal (2000, pp. 877-878). ${ }^{4}$ The Oticon case is reportedly the best-selling IMD case (Gould 1994) ever (Børsens Nyhedsmagasin 8 November, 1999). Kolind's dramatic and symbol-laden way of implementing the spaghetti organization, as well as the form itself, are still being given extensive treatment in management textbooks (e.g., Boddy and Paton 1998).

${ }^{5}$ As Kolind explained to Gould (1994, p. 465): "We quickly agreed that all employees would have a portfolio of jobs, and we were tough; we said at least three jobs, with the main one in their profession or using their greatest competence, and the other two in outside areas. This concept really expands an organization's resources: engineers are doing marketing, marketing people manage development projects, and financial people help with product development."

${ }^{6}$ Although the variance on the distribution of salaries was increased as a result of the new reward schemes, average salaries do not appear to have changed. In fact, average Oticon salaries have been, and still are, comparatively low, particularly for software developers. Intrinsic motivation is a key aspect of Oticon motivation policies, and is seen as complementary to (rather than substituting for) extrinsic motivation. On intrinsic and extrinsic motivation, and its implications for organizational theory, see Frey (1997) and Osterloh and Frey (2000). ${ }^{7}$ Oticon's growth in the 1990s largely represented growth of market share, because the size of the market for hearing aids stagnated in that decade.

${ }^{8}$ Much recent management literature has suggested that firms in volatile elements need to emulate markets to the largest possible extent (e.g., Halal et al. 1993, Cowen and Parker 1997).

${ }^{9}$ For a full comparative analysis, see Nickerson and Zenger (2001).

${ }^{10}$ The possibility that external hybrids or market contracting may be alternatives to internal hybrids never seems to have been considered in Oticon. Thus, that incentives may be strengthened by relying on the real market (rather than the simulated internal one) through spinningoff functions and departments (Aron 1991) does not appear to have been seen as a serious alternative to internal disaggregation.

${ }^{11}$ Exceptions may occur when giving subordinates more extensive rights (e.g., a package of initiation, ratification, and implementation rights) strengthens employee incentives (see Aghion and Tirole 1997, Baker et al. 1999, and Foss and Foss 2002 for analyses of this).

${ }^{12}$ For example, it could reflect attempts to curb moral hazard in project teams. However, the increased use of high-powered incentives and more widespread employee ownership were designed to remedy problems of moral hazard.

${ }^{13}$ The change was assisted by the symbolic acts undertaken by Kolind, which helped to signal his commitment to the change (Hermalin 1998). For example, Kolind invested 25 million Dkr (approximately 4 million USD) of his own funds in the firm.

${ }^{14}$ In addition, a motivation theory perspective would suggest that while employees' lower-level needs were not sufficiently satisfied (low income, uncertainty due to the reorganization and layoffs), management already tried to address their higher-level needs (more comprehensive tasks, more responsibility). Thanks to an anonymous reviewer for this point.
${ }^{15}$ Eskerod $(1997,1998)$ in particular documents this. My later interview with the chief HRM officer strongly confirmed Eskerod's finding that the multijob concept had severe costs in terms of problems of coordination and frustrating employees.

${ }^{16}$ And neither would this have been possible, as nobody in Oticon, not even the Projects and Products Committee, kept track of the total number of development projects. Records were only kept of the 10-20 major projects. An estimate is that under the spaghetti organization, an average of 70 projects were continously running (Eskerod 1998, p. 80).

${ }^{17}$ In fact, the more structured project organization gradually implemented from 1996 has established controls that secure that the coordination and time-allocation problems that beset the original spaghetti organization are kept at bay.

${ }^{18}$ Interview with HRM manager Henrik Holck.

${ }^{19}$ Somewhat later, the literature on internal transfer prices revealed the existence of various incentive problems that may beset this organizational practice (e.g., Holmström and Tirole 1991).

${ }^{20}$ This should be understood in a broad sense: A "project" may refer to many different types of decisions or clusters of decisions.

${ }^{21}$ See Simons (2002) for a highly pertinent discussion of employees' perception of the fit between managers' words and actions and the motivational consequences of this perception.

${ }^{22}$ Since behavior was apparently difficult to measure, a more outputbased system could have been tried (Prendergast 1999), for example, contracts that specified rewards for specific accomplishments (e.g., a system that rewarded according to milestones in a development project). However, it is doubtful whether such a contract could actually be made court enforceable. A managerial commitment problem would again result.

\section{References}

Aghion, Philippe, Jean Tirole. 1997. Formal and real authority in organization. J. Political Econom. 105 1-29.

Argyres, Nicholas, Vai-Lam Mui. 2000. Rules of engagement, informal leaders, and the political economy of organizational dissent. Unpublished paper.

Aron, Debra J. 1991. Using the capital market as a monitor: Corporate spin-offs in an agency framework. RAND J. Econom. 22 $505-518$

Baker, George, Robert Gibbons, Kevin J. Murphy. 1999. Informal authority in organizations. J. Law, Econom. Organ. 15 56-73.

_,$\ldots$ 2002. Relational contracts and the theory of the firm. Quart. J. Econom. 117 39-83.

Barney, Jay B. 1986. Organizational culture: Can it be a source of sustained competitive advantage? Acad. Management Rev. 11 656-665.

Baron, James N., David M. Kreps. 1999. Consistent human resource practices. California Management Rev. 41 29-53.

Barzel, Yoram. 1997. Economic Analysis of Property Rights. Cambridge University Press, Cambridge, MA.

Bazerman, Max H. 1994. Judgment in Managerial Decision Making. Wiley, New York.

Boddy, David, Robert Paton. 1998. Management: An Introduction. Prentice Hall, London, U.K. 
Børsens Nyhedsmagasin. 1991. For Gud, Schrøder og Oticon. (1 Marts).

1999. Opgør med Kolinds kaos. (8 November) 14-22.

Brockner, J., T. Tyler, R. Cooper-Schneider. 1992. The influence of prior commitment to an institution on reactions to perceived unfairness: The higher they are, the harder they fall. Admin. Sci. Quart. 37 241-261.

Business Intelligence. 1993. A non-traditional performance and process measurement system. Mette Morsing, Kristian Eiberg, eds. Managing the Unmanageable for a Decade. Oticon, Hellerup, Denmark.

Casson, Mark. 1994. Why are firms hierarchical? Internat. J. Econom. Bus. 1 47-76.

Coase, Ronald H. 1937. The nature of the firm. Economica (N.S.) 4 386-405.

Cowen, Tyler, David Parker 1997. Markets in the Firm: A Market Process Approach to Management. The Institute of Economic Affairs, London, U.K.

Daft, Richard L., Arie Lewin. 1993. Where are the theories for the "new" organizational forms? An editorial essay. Organ. Sci. 4 i-iv.

Day, Jonathan, Jim Wendler. 1998. The new economics of organization. McKinsey Quart. 23 4-18.

Demsetz, Harold. 1988. The theory of the firm revisited. J. Law, Econom. Organ. 4 141-161.

Dewatripont, Matthias, G. Roland. 1995. The design of reform packages under uncertainty. Amer. Econom. Rev. 85 1207-1223.

Dosi, Giovanni. 1982. Technological paradigms and technological trajectories. Res. Policy 11 147-162.

Eskerod, Pernille. 1997. Nye perspektiver på fordeling af menneskelige ressourcer $i$ et projektorganiseret multiprojekt-miljø. Ph.D. thesis, Handelshøjskole Syd, Sønderborg.

- 1998. Organising by projects: Experiences from Oticon's product development function. Mette Morsing, Kristian Eiberg, eds. Managing the Unmanageable for a Decade. Oticon, Hellerup, Denmark.

Fama, Eugene, Michael C. Jensen. 1983. Separation of ownership and control. J. Law and Econom. 26 301-325.

Foss, Nicolai J. 2002. "Coase vs Hayek" Economic organization and the knowledge economy. Intern. J. Econom. Bus. 9 9-36.

— Kirsten Foss. 2002. Authority and discretion: Tensions, credible delegation, and implications for new organizational forms. Downloadable from http://www.cbs.dk/link/papers

Frey, Bruno. 1997. Not Just for the Money. Edward Elgar, Aldershot, U.K.

Galbraith, Jay R. 1974. Organization design: An information processing view. Interfaces 4 28-36.

Ghemawat, Pankaj, Joan E. Ricart i Costa. 1993. The organizational tension between static and dynamic efficiency. Strategic Management J. 14 59-73.

Gifford, Sharon. 1992. Allocation of entrepreneurial attention. J. Econom. Behavior and Organ. 19 265-284.

Glaser, B., A. Strauss. 1967. The Discovery of Grounded Theory. Aldine, Chicago, IL.
Gould, R. Morgan. 1994. Revolution at Oticon A/S: The spaghetti organization. Soumitra Dutta, Jean-Francois Manzoni, eds. 1999. Process Re-engineering, Organizational Change and Performance Improvement. McGraw-Hill, London, U.K.

Grant, Robert M. 1996. Prospering in dynamically-competitive environments: Organizational capability as knowledge integration. Organ. Sci. 7 375-387.

Halal, William E., K. B. Taylor. 1998. Twenty-First Century Economics: Perspectives of Socioeconomics for a Changing World. St. Martin's Press, New York.

_ _ Ali Geranmayeh, John Pourdehnad. 1993. Internal Markets: Bringing the Power of Free Enterprise Inside Your Organization. Wiley, New York.

Hart, Oliver. 1995. Firms, Contracts and Financial Structure. Clarendon Press, Oxford, U.K.

Hayek, Friedrich A. von. 1945. The use of knowledge in society. in idem. 1948. Individualism and Economic Order. University of Chicago Press, Chicago, IL.

Helper, Susan, John Paul MacDuffie, Charles Sabel. 2000. Pragmatic collaborations: Advancing knowledge while controlling opportunism. Indust. and Corporate Change 9 443-487.

Hemmer, Thomas. 1995. On the interrelation between production technology, job design, and incentives. J. Accounting and Econom. 19 209-245.

Hermalin, Benjamin. 1998. Toward an economic theory of leadership: Leading by example. Amer. Econom. Rev. 88 1188-1206.

Holmström, Bengt. 1999. The firm as a subeconomy. J. Law, Econom. Organ. 15 74-102.

__ Paul Milgrom. 1991. Multitask principal-agent analyses: Incentive contracts, asset ownership, and job design. J. Law, Econom. Organ. 7 24-52.

_ management. Quart. J. Econom. 101 835-860.

_ Jean Tirole. 1991. Transfer pricing and organizational form. $J$. Law, Econom. Organ. 7 201-228.

Jensen, Frank Dybdal. 1998. Vardibaseret Ledelse-styring mellem regler og visioner. Jurist- og Økonomforbundets Forlag, Copenhagen, Denmark.

Jensen, Michael C., William H. Meckling. 1992. Specific and general knowledge and organizational structure. Lars Werin, Hans Wijkander, eds. 1992. Contract Economics. Blackwell, Oxford, U.K.

_ quality management. Michael C. Jensen, ed. Foundations of Organizational Strategy. Harvard University Press, Cambridge, MA.

Kogut, Bruce, Udo Zander. 1992. Knowledge of the firm, combinative capabilities, and the replication of technology. Organ. Sci. 3 387-397.

Kolind, Lars. 1990. Think the unthinkable. Mette Morsing, Kristian Eiberg, eds. 1998. Managing the Unmanageable For a Decade. Oticon, Hellerup, Denmark.

1994. The knowledge-based enterprise. Mette Morsing, Kristian Eiberg, eds. 1998. Managing the Unmanageable for a Decade. Oticon, Hellerup, Denmark. 
LaBarre, Polly. 1996. This organization is dis-organization. Wysiwyg// 93/http://fastcompany.com/online/03/oticon.html

Laursen, Keld, Nicolai J. Foss. 2002. New HRM practices, complementarities, and the impact on innovation performance. Cambridge J. Econom. Forthcoming.

Lazear, Edward. 1995. Personnel Economics. MIT Press, Cambridge, MA.

Liebeskind, Julia Porter. 1996. Knowledge, strategy and the theory of the firm. Strategic Management J. 17 441-452.

Lindenberg, Siegwart. 2000. It takes both trust and lack of mistrust: The workings of cooperation and relational signaling in contractual relationships. J. Management and Governance 4 11-33.

Lotz, Peter. 1998. The paradox of high R\&D and industry stability: Technology and structural dynamics in the global hearing instruments industry. Indust. Innovation 5 113-137.

Lovas, Bjorn, Sumantra Ghoshal. 2000. Strategy as guided evolution. Strategic Management J. 21 875-896.

Lyregaard, Poul-Erik. 1993. Oticon: Erfaringer og faldgruber. Steen Hildebrandt, Leif H. Alken, eds. På vej mod helhedssyn i ledelse. Ankerhus.

Mandag Morgen. 1991. Oticon satser dristigt, men resultaterne mangler. (15 Feb.) 15-18.

Meyer, Alan D., Anne S. Tsui, C.R. Hinings. Configurational approaches to organizational analysis. Acad. Management J. 36 $1175-1195$.

Miles, Raymond E., Charles C. Snow. 1992. Causes of failure in network organizations. California Management Rev. 35 53-72.

_ $\_$, John A. Mathews, Grant Miles, Henry J. Coleman, Jr. 1997. Organizing in the knowledge age: Anticipating the cellular form. Acad. Management Executive 11 7-20.

Milgrom, Paul. 1988. Employment contracts, influence activities and efficient organization design. J. Political Econom. 96 42-60.

_ John Roberts. 1990. The economics of modern manufacturing: technology, strategy and organization. Amer. Econom. Rev. 80 511-528.

Miller, Gary. 1992. Managerial Dilemmas. Cambridge University Press, Cambridge, MA.

Morsing, Mette. 1995. Omstigning til Paradis? Oticon i processen fra hierarki til spaghetti. Copenhagen Business School Press, Copenhagen, Denmark.

_ Kristian Eiberg, eds. 1998. Managing the Unmanageable for a Decade. Oticon, Hellerup, Denmark.

Mosakowski, Elaine. 1998. Entrepreneurial resources, organizational choices, and competitive outcomes. Organ. Sci. 9 625-643.

Nahapiet, Janine, Sumantra Ghoshal. 1999. Social capital, intellectual capital, and the organizational advantage. Acad. Management Rev. 23 242-266.

Nickerson, Jackson, Todd Zenger. 2000. Being efficiently fickle: A dynamic theory of organizational choice. Unpublished paper, David Eccles School of Business, University of Utah.

- -2001 . A knowledge-based theory of governance choice: A problem-solving approach. Unpublished paper, David Eccles School of Business, University of Utah.
North, Douglass C. 1990. Institutions, Institutional Change, and Economic Performance. Cambridge University Press, Cambridge, MA.

Osterloh, Margit, Bruno Frey. 2000. Motivation, knowledge transfer and organizational form. Organ. Sci. 11 538-550.

Peters, Tom. 1992. Liberation Management. Alfred A. Knopf, New York.

Poppo, Laura. 1995. Influence activities and strategic coordination: Two distinctions of internal and external markets. Management Sci. 41 1845-1859.

Poulsen, Per Thygesen. 1993. Taenk det utcenkelige-revolutionen $i$ Oticon. Schultz, Copenhagen, Denmark.

Prendergast, Canice. 1999. The provision of incentives in firms. J. Econom. Literature 37 7-63.

Ravasi, Davide, Gianmario Verona. 2000. Organizing the process of knowledge integration: The benefits of structural ambiguity. Scandinavian J. Management. Forthcoming.

Robinson, S. L., E. W. Morrison. 1995. Organizational citizenship behaviour: A psychological contract perspective. J. Organ. Behaviour 16 289-298.

—, Denise M. Rousseau. 1994. Violating the psychological contract: Not the exception but the norm. J. Organ. Behaviour 15 245-259.

Simons, Tony. 2002. Behavioral integrity: The perceived alignment between managers' words and deeds as a research focus. Organ. Sci. 13 18-35.

Teece, David J., Giovanni Dosi, Richard P. Rumelt, Sidney G. Winter. 1994. Understanding corporate coherence: Theory and evidence. J. Econom. Behavior and Organ. 23 1-30.

Thompson, James D. 1967. Organizations in Action. McGraw-Hill, New York.

Vancil, Robert, Lee E. Buddrus. 1979. Decentralization: Managerial Ambiguity by Design. Irwin, Homewood, IL.

Verona, Gianmario, Davide Ravasi. 1999. Organizational capabilities for continuous innovation. Unpublished paper, Bocconi University.

von Hippel, Eric. 1994. "Sticky information" and the locus of problem solving: Implications for innovation. Management Sci. $\mathbf{4 0}$ 429-439.

von Mises, Ludwig. 1949. Human Action. Fox and Wilkes, San Francisco, CA.

Williamson, Oliver E. 1996. The Mechanisms of Governance. Oxford University Press, Oxford, U.K.

Yin, Robert K. 1989. Case Study Research: Design and Methods. Sage, London, U.K.

Zenger, Todd. 2002. Crafting internal hybrids: Complementarities, common change initiatives, and the team-based organization. Intern. J. Econom. Bus. Forthcoming.

, William S. Hesterly. 1997. The disaggregation of corporations: Selective intervention, high-powered incentives, and molecular units. Organ. Sci. 8 209-222.

Zucker, Lynne. 1991. Markets for bureaucratic authority and control: Information quality in professions and services. Res. Sociology of Organ. 8 157-190. 